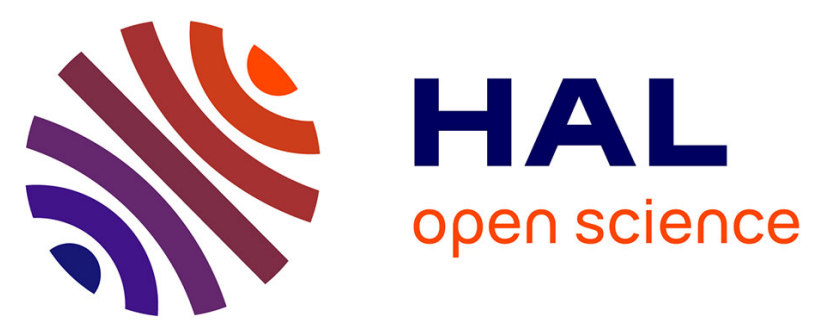

\title{
A systematic literature review of observational studies of the bidirectional association between metabolic syndrome and migraine
}

Valentina A. Andreeva, Pilar Galan, Chantal Julia, Léopold K. Fezeu, Serge Hercberg, Emmanuelle Kesse-Guyot

\section{To cite this version:}

Valentina A. Andreeva, Pilar Galan, Chantal Julia, Léopold K. Fezeu, Serge Hercberg, et al.. A systematic literature review of observational studies of the bidirectional association between metabolic syndrome and migraine. Journal of Diabetes \& Metabolism, 2019, 45 (1), pp.11-18. 10.1016/j.diabet.2017.12.004 . hal-02418746

\author{
HAL Id: hal-02418746 \\ https://hal.science/hal-02418746
}

Submitted on 21 Oct 2021

HAL is a multi-disciplinary open access archive for the deposit and dissemination of scientific research documents, whether they are published or not. The documents may come from teaching and research institutions in France or abroad, or from public or private research centers.
L'archive ouverte pluridisciplinaire HAL, est destinée au dépôt et à la diffusion de documents scientifiques de niveau recherche, publiés ou non, émanant des établissements d'enseignement et de recherche français ou étrangers, des laboratoires publics ou privés.

\section{(ㄷ)(1) $\$$}

Distributed under a Creative Commons Attribution - NonCommerciall 4.0 International 


\section{A systematic literature review of observational studies of the bidirectional association between metabolic syndrome and migraine}

Valentina A. Andreeva*a, Pilar Galan ${ }^{\mathrm{a}}$, Chantal Juliaa ${ }^{\mathrm{a}, \mathrm{b}}$, Léopold Fezeu ${ }^{\mathrm{a}}$, Serge Hercberga, Emmanuelle Kesse-Guyot ${ }^{\mathrm{a}}$

${ }^{\text {a }}$ Equipe de Recherche en Epidémiologie Nutritionnelle (EREN), Centre de Recherche en Epidémiologie et Statistiques, Université Paris 13/Inserm U1153/Inra U1125/ Cnam, COMUE Sorbonne Paris Cité, F-93017 Bobigny, France

b Département de Santé Publique, Hôpital Avicenne, F-93017 Bobigny, France

\section{* Corresponding author:}

Valentina A. Andreeva, Ph.D.

Equipe de Recherche en Epidémiologie Nutritionnelle (EREN)

SMBH Université Paris 13, 74 rue Marcel Cachin, 93017 Bobigny, France

Tel. +3314838 8930; Fax: +3314838 8931;

email: v.andreeva@eren.smbh.univ-paris13.fr

Funding: This research did not receive any specific grant from funding agencies in the public, commercial, or not-for-profit sectors.

Conflicts of interest: None

Abbreviations: CI, confidence interval; MeSH, Medical subject headings; MetS, metabolic syndrome; NIH, National Institutes of Health; OR, odds ratio

Received 17 July 2017; Accepted 7 December 2017 


\section{Abstract}

Aims: To evaluate all epidemiological evidence in the literature linking the metabolic syndrome (MetS) and migraine in adults.

Methods: Database (Medline, Embase; published reports up to November 2017) and manual searches were performed. Information on data collection, sample characteristics, study design, MetS and migraine assessment, and results was extracted from each relevant publication. The methodological quality of each study was also assessed.

Results: A total of 15 observational epidemiological studies in adults, published between 2009 and 2017, were retrieved. Of these, one employed a prospective design, while the rest had a cross-sectional (13 studies) or case-control (one study) design. Five studies assessed the presence of migraine in individuals with MetS, whereas 10 studies assessed the presence or risk of MetS in migraineurs. Most participants were female hospital outpatients. The sole prospective cohort study reported 11-year MetS incidences of $21.8 \%$ in migraineurs with aura, $16.8 \%$ in migraineurs without aura and $14.5 \%$ in subjects without headaches. Most studies $(60 \%)$ provided no statistical estimates of association. Methodological flaws included selection biases, lack of power analysis, unsuitable research plans and no multivariable analyses. Meta-analysis was not feasible with the available data.

Conclusion: Our systematic review has identified major gaps in knowledge and weaknesses in research that should provide an impetus for future epidemiological investigations using more rigorous methodology, larger general-population prospective cohorts, and substantial data on dietary behaviours and lifestyle.

Keywords: Comorbidity; Metabolic syndrome; Migraine; Obesity; Public health 


\section{Introduction}

The Global Burden of Disease Study 2015 [1] placed migraine as the seventh leading cause of years lived with disability. This is a primary headache disorder with unilateral, recurring attacks of moderate-to-severe pain intensity and concurrent photophobia, phonophobia and nausea $[2,3]$. In pathophysiological terms, two distinct disorders-migraine without aura and migraine with aura-are known [4]. The aura most likely has a cerebral cortical origin [5], so migraine with aura is characterized by visual, sensory or other central nervous system symptoms that usually develop gradually and precede migraine attacks [3]. The prevalence of migraine shows notable variation by region, although headache disorders in general are underestimated all over the world [2]. Migraine has been associated with an increased risk of cardiovascular disease, psychiatric and neurological disorders, and obesity $[6,7]$. Moreover, in some individuals, migraine undergoes clinical transformation from an episodic ( $\leq 14$ days of headache/month) to a chronic ( $\geq 15$ days of headache/month) state, underpinned by alterations in nociceptive thresholds and pain pathways and, occasionally, the emergence of brain lesions [5, 8]. Individuals with chronic migraine and those suffering from migraine with aura appear more likely to experience comorbidities (depression, hypertension, diabetes, obesity, respiratory disorders) compared with their counterparts with episodic migraine or migraine without aura [9-11].

Long-term migraine and increased attack frequencies have been associated with cardiometabolic characteristics of migraineurs, such as higher Framingham risk scores, dyslipidaemia, insulin resistance and obesity, all of which are features of the metabolic syndrome (MetS) [12-14]. Indeed, pharmacological treatment of migraine may include medications stimulating weight gain, hypertension and/or dyslipidaemia [15-17]. Conversely, MetS (and obesity in particular) has been suggested as a risk factor for migraine progression possibly via inflammatory and immune-system mediators $[9,16,18]$. MetS—an established 
predictor of diabetes, atherosclerosis and cardiovascular disease [19]—is considered present when three or more of the following criteria are met: abdominal obesity (waist circumference $\geq 94 \mathrm{~cm}$ for men, $\geq 80 \mathrm{~cm}$ for women, although other cut-offs may also be used); hypertension (systolic/diastolic blood pressure $\geq 130 / 85 \mathrm{mmHg}$ and/or use of antihypertensive treatment); raised triglycerides $(\geq 1.7 \mathrm{mmol} / \mathrm{L}$ or medication use); low high-density lipoprotein (HDL) cholesterol $(<1.00 \mathrm{mmol} / \mathrm{L}$ for men, $<1.30 \mathrm{mmol} / \mathrm{L}$ for women); and raised fasting glucose levels ( $\geq 5.6 \mathrm{mmol} / \mathrm{L}$ and/or use of antidiabetic treatment) [20]. The prevalence of each MetS component, the cut-off values and, thus, MetS overall vary across regions [20-22]. For example, using aggregated 2003-2012 data, the prevalence of MetS in the US was estimated at $33 \%$ [21].

Yet, given the current knowledge, it remains unclear whether migraine is more likely to act as a progressive trigger of MetS or vice versa. It is likewise unconfirmed whether the MetS-migraine association consistently varies by type of migraine (chronic, episodic, with or without aura) and/or by age and gender. The prevalence of migraine is most likely highest before age 45, and is twice as common in women than in men [2]. Conversely, the prevalence of MetS increases with age and is highest after age 60 [21]. With the present systematic review, the aim was to evaluate the epidemiological evidence linking these two disorders to provide a comprehensive understanding of their association, identify any consistent moderating factors and outline the direction of future investigations.

\section{Methods}

Our intention was to synthesize data from all observational epidemiological studies with a bearing on the link between MetS and migraine in adults. An extensive search was therefore performed of Embase and Medline/PubMed (all available reports from the beginning of database indexing up to November 2017), supplemented by a manual search 
through the reference lists of retrieved articles. Published conference proceeding abstracts were also considered. No language restrictions were applied. MeSH indexing terms 'metabolic syndrome $\mathrm{X}$ ' and 'abdominal obesity metabolic syndrome' were associated with 'migraine disorders', 'migraine without aura', 'migraine with aura', 'headache', 'headache disorders, primary' and 'headache disorders'. A total of 253 and 17 articles were identified from database and manual searches, respectively. From the pool of non-duplicated hits, all review articles (with no original data) and research reporting on individual MetS components, but not MetS itself, were excluded. Ultimately, a total of 15 studies met the selection criteria (Fig. 1) and were subjected to detailed reviews performed independently by two investigators (V.A.A. and E.K.-G.). From each study, the following information was extracted: place and year of data collection; type and size of sample; study design; MetS and migraine assessment criteria; migraine treatment; and results [prevalence, incidence, odds ratio (OR) or other estimates of association, statistical adjustment]. In our summary of findings, the term 'presence' was employed when referring to estimates obtained from cross-sectional and casecontrol (retrospective) studies, and the term 'risk' was used when referring to estimates obtained from prospective studies.

Also assessed was the methodological rigour of each selected study, according to a US National Institutes of Health (NIH)-derived quality-assessment tool [23]. Owing to the lack of statistical estimates of association in most of the reviewed studies and the heterogeneity of the reference categories (in studies providing such estimates), meta-analysis of the available data was not feasible. Because this systematic review was based exclusively on publicly available published literature, it was exempt from ethics committee review. However, the Meta-analysis of Observational Studies in Epidemiology (MOOSE) Checklist [24] was completed.

\section{Results}


Settings, study samples and definitions

Our summarized findings are presented in Table I. Of the 15 reviewed studies (all English language, published between 2009 and 2017), only one employed a prospective design, whereas the rest had a cross-sectional (13 studies) or case-control (one study) design. The research came from countries in Europe, North and South America, Asia and Middle East. Although most study samples $(73 \%)$ comprised female hospital outpatients, there was a substantial diversity in reference (comparison) groups owing to wide disparities in inclusion criteria.

Given that different MetS guidelines have been advanced [20, 25, 26], most studies employed those that were current at the time of the research. The principal difference among the various MetS definitions was whether or not central obesity is an obligatory component with agreed-upon cut-offs [20] whereas, in general, larger waist circumference thresholds were used in North America than in the rest of the world [20]. In turn, the definition of migraine followed International Headache Society criteria in 11 studies (73\%), half of which also assessed the severity of migraine via a visual analogue scale [27]. Migraine treatment was inconsistently reported: three studies specifically excluded regular users of antimigraine drugs $[17,28,29]$; and one study included only participants taking chronic migraine treatment [30].

\section{Presence of migraine in subjects with MetS}

Five studies (33\%) dealt with the presence of migraine (dependent variable) in subjects with MetS (independent variable). Sample sizes ranged from 60 to 980 individuals with MetS, while mean ages ranged from 40.8 to 54.4 years. All five studies employed crosssectional analyses. The presence of migraine in those with MetS also varied greatly (from $2.8 \%$ to $58.3 \%$ ), with marked disparities regarding reference groups. Only one of the five 
studies reported a statistical estimate of association, with a non-significant OR of 1.18 (95\% CI: 0.72-1.92) adjusted for age and gender [31]. Two studies evoked gender-specific differences, with MetS females being more likely to report migraine (overall or episodic) than were MetS males [32, 33].

\section{Presence (or risk) of MetS in those with migraine}

Regarding MetS (dependent variable) in individuals with migraine (independent variable), eight studies employed cross-sectional analyses, one study used a case-control design and another study assessed the incidence of MetS using a prospective design. Sample sizes ranged from 22 to 4411 migraineurs, with mean ages ranging from 31.4 to 50.0 years. In the cross-sectional studies, the presence of MetS in migraineurs ranged from $12 \%$ to $33 \%$, with marked disparities among comparator groups. Three of the cross-sectional studies reported ORs, none of which were similar. Specifically, a Brazilian study of current/former civil servants revealed a significant inverse association between MetS and definite migraine only among men (adjusted OR: 0.65, 95\% CI: 0.43-0.99) [34], whereas positive associations were noted for chronic migraine in a Chinese study of female outpatients (adjusted OR: 5.34, 95\% CI: 1.16-24.6) [17] and for migraine with aura in a Belgian general-population-based cohort (adjusted OR: 3.45, 95\% CI: 1.63-7.29) [35]. However, disparities were observed in their multivariable adjustments.

A prospective general-population cohort in Norway revealed an 11-year incidence of MetS of $21.8 \%$ in migraineurs with aura, $16.8 \%$ in migraineurs without aura and $14.5 \%$ in those with no headaches [36]. Furthermore, significant effect modification by smoking status was observed, with adjusted incidence risk ratios for development of MetS of 2.10 (95\% CI: 1.53-2.89) among migraineurs with aura who were smokers, 1.39 (95\% CI: 1.03-1.86) 
among migraineurs with aura who were non-smokers, and 1.26 (95\% CI: 1.12-1.42) in migraineurs without aura irrespective of smoking status [36].

\section{Associations by aura status}

The type of migraine as regards the presence of aura was inconsistently evaluated, and one study included only migraineurs without aura [37]. Of the studies evaluating the MetSmigraine association according to aura status, four of them reported non-significant findings $[17,29,32,38]$. Also, as noted above, the presence (and risk) of MetS was increased in migraineurs with aura compared with migraineurs without aura and non-migraineurs $[35,36]$.

\section{Associations with chronic migraine}

Chronic and episodic migraine was not systematically distinguished, while one study included only those with chronic migraine [30]. As noted above, another study revealed a significant positive association between MetS and chronic migraine in female outpatients [17]. Finally, a non-significant adjusted OR of 0.88 (95\% CI: 0.79-1.16) was reported for the association of MetS with either chronic or episodic migraine [39].

\section{Study-quality assessment}

Substantial variability was observed across studies regarding methodological rigour and quality (Table S1; see supplementary materials associated with this article online). While research objectives were often clearly stated, most studies proposed no specific hypotheses. Only one study performed a preliminary power analysis and sample-size calculation [32]. Other methodological deficiencies, identified by an NIH-derived quality-assessment tool for observational epidemiological studies, included a frequent lack of information on response rates, insufficient information on recruitment strategies, a strong potential for selection biases, 
use of unsuitable research plans (especially in studies reporting recruitment of control participants, yet performing cross-sectional analyses) and a frequent absence of multivariable analysis. In fact, nine of the 15 studies provided no statistical estimates of association [OR, relative risk $(\mathrm{RR})]$.

\section{Discussion}

To the best of our knowledge, this is the first systematic review to address the quantity and quality of published epidemiological research on the association between MetS and migraine. Interest in this domain appears to be relatively recent, as all 15 reviewed studies were published between 2009 and 2017. Possibly driven by the greater prevalence of migraine in women than in men, the large majority of research participants were women. Five studies addressed the presence of migraine in people with MetS, whereas the remaining 10 addressed the presence of MetS in those with migraine. However, marked disparities in inclusion/exclusion criteria highlighted important differences in reference (comparator) groups, thereby reflecting negatively on the reliability of the current data on the MetSmigraine association, and precluding any inferences of MetS prevalence in people with migraine and vice versa. Even though a large majority of our reviewed studies included hospital outpatients, the specific selection criteria varied from none [40] to exclusion of subjects who were pregnant or had malignancies, or hepatic, renal or heart failure, diabetes, hyperlipidaemia, hypertension, thyroid disease, anaemia, morbid obesity, were smokers or consumed alcohol [29]. Age restrictions also varied from none [30] to 18-65 years [17] and 20-70 years [32]. Overall, participants were recruited from endocrinology/internal medicine/diabetes outpatient clinics, workplaces, headache/neurology clinics and the general population. Such considerations, coupled with the frequent absence of statistical estimates of association, precluded meta-analysis. However, meta-analyses of observational studies of the 
association between one MetS component (obesity, as assessed by body mass index) and migraine were feasible, revealing significant positive associations [41, 42].

Some authors have indicated that migraine is associated with MetS incidence primarily among younger individuals whose cardiovascular risk is generally lower whereas, in their older counterparts, neurovascular changes, neuropathy and/or selective survival may obscure the link or even lead to seemingly protective effects [43]. Our present review, however, revealed no age-specific associations. Also, only one of our 15 studies reported that MetS was more common in elderly female migraineurs, with multiple triggers and longer durations of headache compared with their younger counterparts [38]. However, that study failed to perform any multivariable analyses. Even though the present review was focused on MetS in general, it was nevertheless clear that no individual MetS component emerged as significantly related to migraine in any consistent fashion.

Previous literature reports have documented that migraineurs with aura are at increased odds of having unfavourable cardiometabolic profiles, elevated Framingham risk scores [11, 13] and comorbidities [10]. In the present review, two studies reported that the presence (and risk) of MetS was increased in migraineurs with aura compared with migraineurs without aura and non-migraineurs [35, 36]. However, type of migraine as regards aura status was not systematically assessed, thereby making it not possible, given the paucity and limitations of the available data, to conclude whether the MetS-migraine association consistently varies by aura status. Migraines with and without aura are, in fact, distinct entities with disparate pathophysiologies and symptomatologies [3, 4]. Likewise, the reviewed studies failed to systematically distinguish between chronic and episodic migraines. The former results from a series of clinical, physiological and anatomical transformations [5, 8], and sufferers of chronic migraine, unlike their counterparts with episodic migraine, have an increased likelihood of experiencing physical and mental comorbidities such as 
hypertension, diabetes, obesity, respiratory disorders, depression and anxiety disorders [9]. The present review, in fact, found only one study showing a significant positive association between MetS and chronic migraine [17].

Most of our reviewed studies provided no statistical estimates of association (OR, RR), which was a major methodological flaw. In the studies not reporting such estimates, multivariable adjustments varied from controlling for age and gender [31] to controlling for age, gender, residential district, sedentariness, smoking, and family history of myocardial infarction, stroke and hypertension $[35,36]$. In addition, only one of our studies employed formal interaction tests to reveal that the MetS-migraine association differed by smoking status [36]. Furthermore, only one of our studies revealed gender-specific statistical estimates of association, yet reported no formal interaction tests. Specifically, the presence of MetS was lower in men than in women [34]. Thus, consistent, statistically supported moderating factors of the MetS-migraine association could not be identified from the presently available data.

Although the side-effects of migraine treatment can include MetS components (weight gain, hypertension, dyslipidaemia) [15-17], in our reviewed studies, migraine treatment (and its role) was inconsistently reported. Apart from the side-effects of such pharmacological treatments, the association between MetS (and vascular disorders in general) and migraine has been addressed by previous research into underlying pathophysiological abnormalities, including inflammation, insulin resistance, hypothalamic and endothelial dysfunction, and high levels of leptin and orexin A [36, 44-46]. Moreover, the association of migraine with some of these abnormalities has been shown to be amplified by obesity [39].

Methodological flaws of the reviewed studies included a frequent lack of information on response rates, no details on recruitment strategies, a strong potential for selection bias and use of unsuitable research plans. Only one of our 15 studies performed a preliminary power analysis and sample-size calculation [32]. Furthermore, only 47\% (seven studies) dealt with 
the issue of prevention, mostly evoking weight loss and dietary modification as risk-reduction strategies. Of these, only one [31] addressed prevention in a comprehensive manner. In general, lifestyle-based strategies for prevention of these disorders include not only dietary modification and weight loss, but also stress management, sleep hygiene and physical activity (particularly in cases of MetS) [16], all of which can ameliorate the implicated pathophysiological abnormalities.

The currently rapidly rising rates of obesity and diabetes emphasize the importance of preventative action for both MetS and migraine [47, 48]. The need for implementation of educational and screening programmes, and the involvement of employers, healthcare providers and public-health decision-makers have all been raised [31]. Yet, to our knowledge, this is the first study to evaluate, in a systematic manner, the quantity and quality of the published research pertaining to the association of MetS and migraine. In fact, our review has identified gaps in knowledge and weaknesses in research that should provide an impetus for future epidemiological investigations using more rigorous methodology, large generalpopulation-based prospective cohorts, and substantial data on dietary behaviours and lifestyle.

\section{Appendix supplementary material}

Supplementary materials (Table S1) associated with this article can be found at http://www.scincedirect.com at doi ... 


\section{References}

[1] Global Burden of Disease 2015 Disease and Injury Incidence and Prevalence Collaborators. Global, regional, and national incidence, prevalence, and years lived with disability for 310 diseases and injuries, 1990-2015: a systematic analysis for the Global Burden of Disease Study 2015. Lancet 2016; 388: 1545-602.

[2] World Health Organization. Headache disorders. WHO: Geneva, 2016.

[3] International Headache Society. The International Classification of Headache Disorders, 3rd ed (beta version). Cephalalgia 2013; 33: 629-808.

[4] Chronicle EP, Pearson AJ, Mulleners WM. Objective assessment of cortical excitability in migraine with and without aura. Cephalalgia 2006; 26: 801-8.

[5] Welch KM. Contemporary concepts of migraine pathogenesis. Neurology 2003; 61: S28.

[6] Negro A, D'Alonzo L, Martelletti P. Chronic migraine: comorbidities, risk factors, and rehabilitation. Intern Emerg Med 2010; 5: S13-9.

[7] Kurth T, Winter AC, Eliassen AH, et al. Migraine and risk of cardiovascular disease in women: prospective cohort study. BMJ 2016; 353: i2610.

[8] Bigal M. Migraine chronification - concept and risk factors. Discov Med 2009; 8: 14550.

[9] Buse DC, Manack A, Serrano D, Turkel C, Lipton RB. Sociodemographic and comorbidity profiles of chronic migraine and episodic migraine sufferers. J Neurol Neurosurg Psychiatry 2010; 81: 428-32.

[10] Le H, Tfelt-Hansen P, Russell MB, Skytthe A, Kyvik KO, Olesen J. Co-morbidity of migraine with somatic disease in a large population-based study. Cephalalgia 2011;31: 43-64.

[11] Scher AI, Terwindt GM, Picavet HS, Verschuren WM, Ferrari MD, Launer LJ. Cardiovascular risk factors and migraine: the GEM population-based study. Neurology 2005; 64: 614-20.

[12] Tana C, Tafuri E, Tana M, Martelletti P, Negro A, Affaitati G et al. New insights into the cardiovascular risk of migraine and the role of white matter hyperintensities: is gold all that glitters? J Headache Pain 2013; 14: 9.

[13] Winsvold BS, Hagen K, Aamodt AH, Stovner LJ, Holmen J, Zwart JA. Headache, migraine and cardiovascular risk factors: the HUNT study. Eur J Neurol 2011; 18: 50411 . 
[14] Sinclair AJ, Matharu M. Migraine, cerebrovascular disease and the metabolic syndrome. Ann Indian Acad Neurol 2012; 15: S72-7.

[15] Chai NC, Bond DS, Moghekar A, Scher AI, Peterlin BL. Obesity and headache: Part II - potential mechanism and treatment considerations. Headache 2014; 54: 459-71.

[16] Sachdev A, Marmura MJ. Metabolic syndrome and migraine. Front Neurol 2012; 3: 161.

[17] He Z, Dong L, Zhang Y, Kong Q, Tan G, Zhou J. Metabolic syndrome in female migraine patients is associated with medication overuse headache: a clinic-based study in China. Eur J Neurol 2015; 22: 1228-34.

[18] Lipton RB, Bigal ME. Looking to the future: research designs for study of headache disease progression. Headache 2008; 48: 58-66.

[19] Wilson PW, D'Agostino RB, Parise H, Sullivan L, Meigs JB. Metabolic syndrome as a precursor of cardiovascular disease and type 2 diabetes mellitus. Circulation 2005; 112: 3066-72.

[20] Alberti KG, Eckel RH, Grundy SM, Zimmet PZ, Cleeman JI, Donato KA et al. Harmonizing the metabolic syndrome: a joint interim statement of the International Diabetes Federation Task Force on Epidemiology and Prevention; National Heart, Lung, and Blood Institute; American Heart Association; World Heart Federation; International Atherosclerosis Society; and International Association for the Study of Obesity. Circulation 2009; 120: 1640-5.

[21] Aguilar M, Bhuket T, Torres S, Liu B, Wong RJ. Prevalence of the metabolic syndrome in the United States, 2003-2012. JAMA 2015; 313: 1973-4.

[22] van Vliet-Ostaptchouk JV, Nuotio ML, Slagter SN, Doiron D, Fischer K, Foco L et al. The prevalence of metabolic syndrome and metabolically healthy obesity in Europe: a collaborative analysis of ten large cohort studies. BMC Endocr Disord 2014; 14: 9.

[23] U.S. Department of Health and Human Services, National Institutes of Health, National Heart Lung and Blood Institute. Study quality assessment tools. Updated April 2014, https://www.nhlbi.nih.gov/health-pro/guidelines/in-develop/cardiovascular-riskreduction/tools [accessed 22.11.2017]

[24] Stroup DF, Berlin JA, Morton SC, Olkin I, Williamson GD, Rennie D et al. Metaanalysis of observational studies in epidemiology: a proposal for reporting. Metaanalysis Of Observational Studies in Epidemiology (MOOSE) group. JAMA 2000; 283: 2008-12. 
[25] National Cholesterol Education Program Expert Panel on Detection Evaluation Treatment of High Blood Cholesterol in Adults. Third Report of the National Cholesterol Education Program (NCEP) Expert Panel on Detection, Evaluation, and Treatment of High Blood Cholesterol in Adults (Adult Treatment Panel III) final report. Circulation 2002; 106: 3143-421.

[26] Zimmet PZ, Alberti G. The metabolic syndrome: perhaps an etiologic mystery but far from a myth - where does the International Diabetes Federation stand? Medscape Diabetes Endocrinol 2005; 7.

[27] Jensen MP, Karoly P. Self-report scales and procedures for assessing pain in adults. In: Turk DC, Melzack R, editors. Handbook of pain assessment, 2nd ed. New York: Guilford Press, 2001; p. 15-34.

[28] Hamed SA, Ezz-El-Deen ME, Abdou MA. Migraine in patients with metabolic syndrome: is there a relationship to leptin? Metabolomics 2012; 2: 114.

[29] Celikbilek A, Borekci E, Kozan M, Celikbilek M. Assessment of metabolic syndrome in patients with migraine in central Anatolia. Eur J Gen Med 2015; 12: 152-6.

[30] Anjum MW, Marmura MJ, Young WB. Medication and metabolic syndrome in chronic migraine [Abstract]. Cephalalgia 2009; 29: S33-4.

[31] Schultz AB, Edington DW. Analysis of the association between metabolic syndrome and disease in a workplace population over time. Value Health 2010; 13: 258-64.

[32] Guldiken B, Guldiken S, Taskiran B, Koc G, Turgut N, Kabayel L et al. Migraine in metabolic syndrome. Neurologist 2009; 15: 55-8.

[33] Demiryürek BE, Emre U, Korucu O, et al. Frequency and types of headaches in patients with metabolic syndrome. Ideggyogy Sz 2016; 69: 319-25.

[34] Goulart AC, Santos IS, Lotufo PA, Bensenor IM. Gender aspects of the relationship between migraine and cardiovascular risk factors: a cross-sectional evaluation in the Brazilian Longitudinal Study of Adult Health (ELSA-Brasil). Cephalalgia 2015; 35: 1103-14.

[35] Streel S, Donneau AF, Dardenne N, Hoge A, Albert A, Schoenen J et al. Screening for the metabolic syndrome in subjects with migraine. Cephalalgia 2017; 37: 1180-8.

[36] Winsvold BS, Sandven I, Hagen K, Linde M, Midthjell K, Zwart JA. Migraine, headache and development of metabolic syndrome: an 11-year follow-up in the NordTrondelag Health Study (HUNT). Pain 2013; 154: 1305-11. 
[37] Gozke E, Unal M, Engin H, Gurbuzer N. An observational study on the association between migraines and tension-type headaches in patients diagnosed with metabolic syndrome. ISRN Neurol 2013: 147065.

[38] Bhoi SK, Kalita J, Misra UK. Metabolic syndrome and insulin resistance in migraine. J Headache Pain 2012; 13: 321-6.

[39] Fava A, Pirritano D, Consoli D, Plastino M, Casalinuovo F, Cristofaro S et al. Chronic migraine in women is associated with insulin resistance: a cross-sectional study. Eur $\mathbf{J}$ Neurol 2014; 21: 267-72.

[40] Krongsut S, Tanprawate S. Migraine, metabolic syndrome, and obesity: a crosssectional study [Abstract]. Cephalalgia 2016; 36: S70.

[41] Ornello R, Ripa P, Pistoia F, Degan D, Tiseo C, Carolei A et al. Migraine and body mass index categories: a systematic review and meta-analysis of observational studies. $\mathbf{J}$ Headache Pain 2015; 16: 27.

[42] Gelaye B, Sacco S, Brown WJ, Nitchie HL, Ornello R, Peterlin BL. Body composition status and the risk of migraine: a meta-analysis. Neurology 2017; 88: 1795-804.

[43] Voss JD, Scher AI. Headache linked with incidence of metabolic syndrome: comment on migraine, headache and development of metabolic syndrome: an 11-year follow-up in the HUNT study. Pain 2013; 154: 1163-4.

[44] Gruber HJ, Bernecker C, Pailer S, Lechner A, Horejsi R, Möller R et al. Lipid profile in normal weight migraineurs - evidence for cardiovascular risk. Eur J Neurol 2010; 17: 419-25.

[45] Rist PM, Tzourio C, Kurth T. Associations between lipid levels and migraine: crosssectional analysis in the epidemiology of vascular ageing study. Cephalalgia 2011; 31: 1459-65.

[46] Takeshima T. [Metabolic syndrome and prevention of migraine headache]. Brain Nerve 2009; 61: 1143-53.

[47] Danaei G, Finucane MM, Lu Y, Singh GM, Cowan MJ, Paciorek CJ et al. National, regional, and global trends in fasting plasma glucose and diabetes prevalence since 1980: systematic analysis of health examination surveys and epidemiological studies with 370 country-years and 2.7 million participants. Lancet 2011; 378: 31-40.

[48] World Health Organization. Obesity and overweight. WHO: Geneva, 2017.

[49] Salmasi M, Amini L, Javanmard SH, Saadatnia M. Metabolic syndrome in migraine headache: a case-control study. J Res Med Sci 2014; 19: 13-7. 
Figure legend

Fig. 1. Flow diagram of study selection for the present literature review on the metabolic syndrome (MetS) and migraine. 
Fig. 1

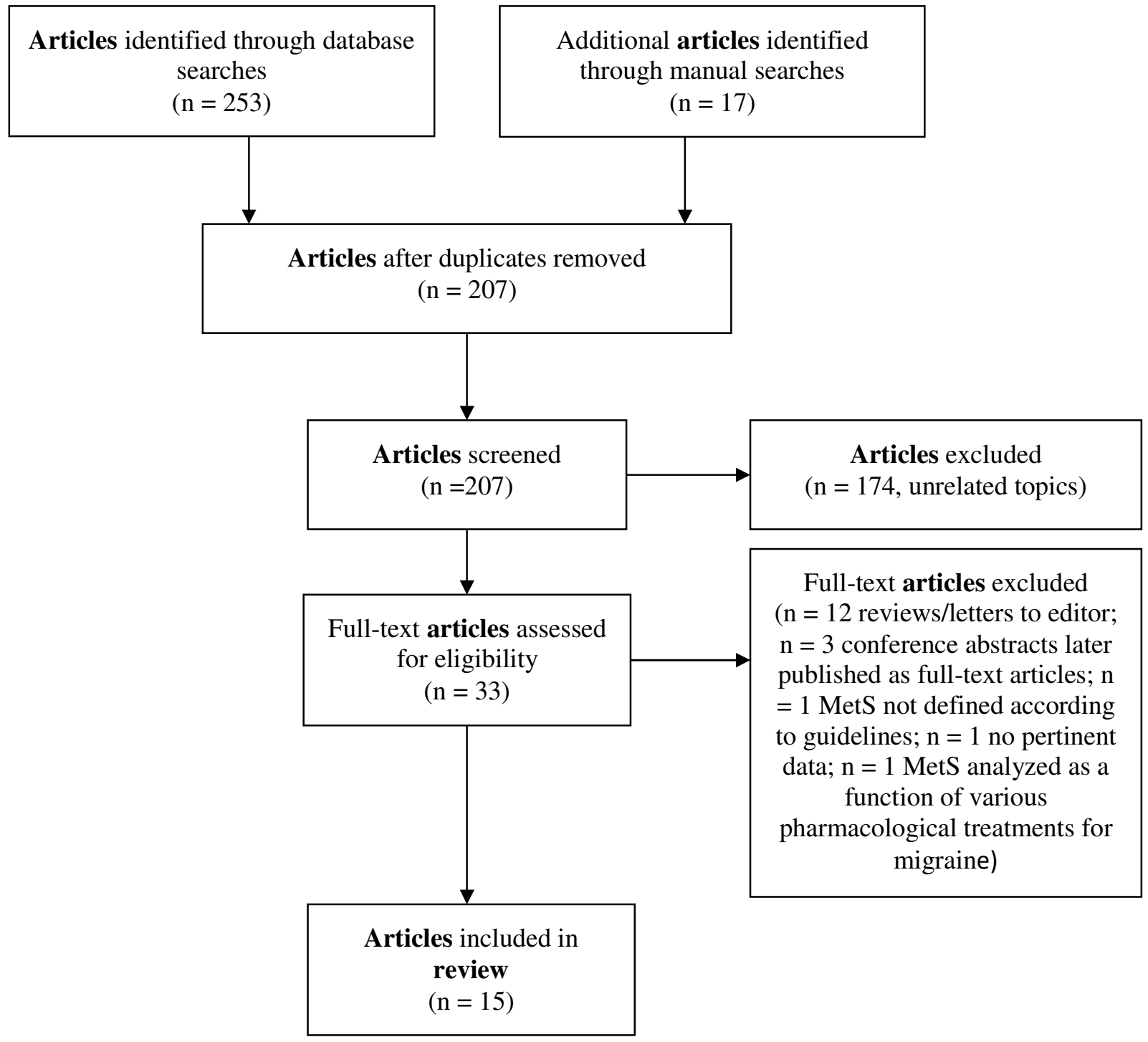


Table I. Summary of observational epidemiological findings on the association between the metabolic syndrome (MetS) and migraine in adults

\begin{tabular}{|c|c|c|c|c|c|c|c|c|c|}
\hline \multirow[b]{2}{*}{ Reference } & \multirow[b]{2}{*}{$\begin{array}{l}\text { Setting \& } \\
\text { period of data } \\
\text { collection }\end{array}$} & \multirow[b]{2}{*}{ Study design } & \multirow[b]{2}{*}{ Sample population } & \multirow[b]{2}{*}{$\begin{array}{c}\text { MetS } \\
\text { assessment }\end{array}$} & \multirow[b]{2}{*}{$\begin{array}{l}\text { Migraine } \\
\text { assessment \& } \\
\text { treatment }\end{array}$} & \multicolumn{4}{|c|}{ Results } \\
\hline & & & & & & $\begin{array}{l}\text { MetS with } \\
\text { migraine } \\
(\%)\end{array}$ & $\begin{array}{c}\text { Migraineurs } \\
\text { with MetS } \\
(\%)\end{array}$ & $\begin{array}{c}\text { OR }(95 \% \mathrm{CI}) \text { or } \\
\text { other risk } \\
\text { estimate }\end{array}$ & Additional results \\
\hline \multicolumn{10}{|c|}{ Presence of migraine in subjects with MetS } \\
\hline $\begin{array}{l}\text { Guldiken et al. } \\
\text { (2009) [32] }\end{array}$ & $\begin{array}{c}\text { Endocrinology } \\
\& \text { internal } \\
\text { medicine } \\
\text { outpatient } \\
\text { clinics, Turkey; } \\
\text { period n/a }\end{array}$ & Cross-sectional & $\begin{array}{l}210 \text { subjects with } \\
\text { MetS }(72 \% \text { female }) \\
\text { ages } 20-70 ; \text { mean } \\
\text { age } 52.4 \pm 9.9\end{array}$ & ATP-III criteria & $\begin{array}{l}\text { Clinical exam; } \\
\text { ICHD-2 criteria } \\
\text { (IHS); VAS; } \\
\text { treatment } \mathrm{n} / \mathrm{a}\end{array}$ & $\begin{array}{c}19.5 \% \\
(11.9 \% \\
\text { male, } \\
22.5 \% \\
\text { female })\end{array}$ & - & - & $\begin{array}{l}\text { Diabetes, increased WC, BMI } \\
\text { more frequent in migraineurs } v s \\
\text { non-migraineurs; hypertension } \\
\text { \& dyslipidaemia NS; NS by } \\
\text { presence of aura; attack } \\
\text { frequency significantly } \\
\text { associated only with BMI }\end{array}$ \\
\hline $\begin{array}{l}\text { Schultz et al. } \\
\text { (2010) [31] }\end{array}$ & $\begin{array}{l}\text { Workplace } \\
\text { health } \\
\text { screening, USA; } \\
\text { 2004-2006 }\end{array}$ & $\begin{array}{l}\text { Prospective } \\
\text { cohort (cross- } \\
\text { sectional } \\
\text { analysis for } \\
\text { migraine) }\end{array}$ & $\begin{array}{c}3285 \text { employees } \\
\text { (17\% female); } \\
\text { MetS: } 29.8 \% \text { in } \\
2004,32.1 \% \text { in } \\
\text { 2006; mean age } \\
40.8\end{array}$ & $\begin{array}{c}\text { AHA/NHLBI } \\
\text { criteria }\end{array}$ & $\begin{array}{l}\text { Self-reported } \\
\text { diagnosis \& } \\
\text { treatment }\end{array}$ & $\begin{array}{l}2.8 \%(2.9 \% \\
\text { in those } \\
\text { without } \\
\text { MetS) }\end{array}$ & - & $\begin{array}{l}1.18(0.72-1.92) \\
\text { adjusted for age, } \\
\text { gender }\end{array}$ & $\begin{array}{c}\text { NS association between MetS \& } \\
\text { migraine; role of migraine } \\
\text { treatment } n / a\end{array}$ \\
\hline $\begin{array}{l}\text { Hamed et al. } \\
(2012)[28]\end{array}$ & $\begin{array}{l}\text { Diabetes } \\
\text { outpatient } \\
\text { clinic, Egypt, } \\
\text { 2010-2011 }\end{array}$ & $\begin{array}{l}\text { Case-control } \\
\text { (cross-sectional } \\
\text { analysis) }\end{array}$ & $\begin{array}{c}60 \text { subjects with } \\
\text { MetS \& headaches } \\
\text { (93.3\% migraine); } \\
\text { ages } 32-55 ; \text { mean } \\
\text { age } 47.8 \pm 7.3,63 \% \\
\text { female; } 40 \text { matched } \\
\text { controls (22.5\% } \\
\text { migraineurs) }\end{array}$ & $\begin{array}{l}\text { 2009 Joint } \\
\text { Interim } \\
\text { Statement } \\
\text { criteria }\end{array}$ & $\begin{array}{l}\text { Clinical exam; } \\
\text { IHS criteria; } \\
\text { excluding } \\
\text { regular users of } \\
\text { antimigraine, } \\
\text { antidiabetic, } \\
\text { antihypertensive } \\
\text { or lipid- } \\
\text { lowering drugs }\end{array}$ & $\begin{array}{l}58.3 \% \mathrm{EM} \\
35 \% \mathrm{CM}\end{array}$ & - & - & $\begin{array}{l}\text { Comorbid migraine with MetS } \\
\text { related to total \& abdominal } \\
\text { adiposity, insulin abnormalities }\end{array}$ \\
\hline $\begin{array}{l}\text { Gozke et al. } \\
\text { (2013) [37] }\end{array}$ & $\begin{array}{c}\text { Hospital } \\
\text { outpatients, } \\
\text { Turkey; period } \\
\text { n/a }\end{array}$ & Cross-sectional & $\begin{array}{l}120 \text { subjects with } \\
\text { MetS ( } 75 \% \text { female); } \\
\text { ages } 29-84 ; \text { mean } \\
\text { age } 54.4 \pm 11.6\end{array}$ & ATP-III criteria & $\begin{array}{l}\text { Clinical exam; } \\
\text { ICHD-2 criteria } \\
\text { (IHS); VAS; } \\
\text { analgestic drug } \\
\text { use }\end{array}$ & $15 \%$ & - & - & $\begin{array}{l}\text { Hypertriglyceridaemia more } \\
\text { common in migraineurs } v s \text { non- } \\
\text { migraineurs; only migraineurs } \\
\text { without aura; NS correlations } \\
\text { between attack frequency \& } \\
\text { each MetS parameter; NS role of } \\
\text { analgestic drug use }\end{array}$ \\
\hline $\begin{array}{l}\text { Demiryürek et al. } \\
\text { (2016) [33] }\end{array}$ & $\begin{array}{l}\text { Endocrinology } \\
\text { outpatient } \\
\text { clinic, Turkey; } \\
\text { 2011-2012 }\end{array}$ & Cross-sectional & $\begin{array}{l}202(80.7 \% \text { female }) \\
\text { ages } 20-70 ; \text { mean } \\
\text { age } 49.9 \pm 11.1\end{array}$ & IDF criteria & $\begin{array}{l}\text { Clinical exam; } \\
\text { IHS criteria; } \\
\text { VAS; analgesic } \\
\text { drug use history }\end{array}$ & $\begin{array}{c}14.4 \% \mathrm{EM} \\
(14.7 \% \\
\text { females, } \\
12.8 \%\end{array}$ & - & - & $\begin{array}{l}\text { Significant correlation between } \\
\text { triglyceride levels \& attack } \\
\text { frequency/severity; role of } \\
\text { migraine treatment n/a }\end{array}$ \\
\hline
\end{tabular}




\begin{tabular}{|c|c|c|c|c|c|c|c|c|c|}
\hline & & & & & \& frequency & $\begin{array}{c}\text { males); } \\
8.4 \% \text { EM + } \\
\text { episodic } \\
\text { tension- } \\
\text { type } \\
\text { headache } \\
(8.6 \% \\
\text { females, } \\
7.7 \% \\
\text { males) } \\
\end{array}$ & & & \\
\hline \multicolumn{10}{|c|}{ Presence of MetS in subjects with migraine } \\
\hline $\begin{array}{l}\text { Anjum et al. } \\
\text { (2009) [30] }\end{array}$ & $\begin{array}{c}\text { University } \\
\text { headache clinic, } \\
\text { USA; period n/a }\end{array}$ & Cross-sectional & $\begin{array}{l}22 \text { subjects treated } \\
\text { for } \mathrm{CM} \text {, ages } 17-59, \\
\text { mean age } 40.5 ; 73 \% \\
\text { female }\end{array}$ & $\mathrm{n} / \mathrm{a}$ & $\begin{array}{l}\text { Assessment n/a; } \\
\text { treated with } \\
\text { topiramate, } \\
\text { nortriptyline, } \\
\text { duloxetine, } \\
\text { venlafaxine }\end{array}$ & - & $13.6 \%$ & - & $\begin{array}{l}\text { Evoked dyslipidaemia as } \\
\text { principal MetS component in } \\
\text { relation to migraine }\end{array}$ \\
\hline $\begin{array}{l}\text { Bhoi et al. (2012) } \\
\text { [38] }\end{array}$ & $\begin{array}{c}\text { Neurology } \\
\text { outpatient } \\
\text { service, India, } \\
\text { 2009-2010 }\end{array}$ & Cross-sectional & $\begin{array}{c}135 \text { migraineurs } \\
\text { (80\% female); ages } \\
14-61 ; \text { mean age } \\
31.4 \pm 10.5\end{array}$ & $\begin{array}{c}\text { ATP-III, IDF } \\
\text { criteria }\end{array}$ & $\begin{array}{l}\text { Clinical exam; } \\
\text { IHS criteria; } \\
\text { treatment n/a }\end{array}$ & - & $31.9 \%$ & - & $\begin{array}{l}\text { MetS more common in elderly } \\
\text { female migraineurs with } \\
\text { multiple triggers, longer } \\
\text { durations of headache; NS by } \\
\text { presence of aura; NS by attack } \\
\text { frequency }\end{array}$ \\
\hline $\begin{array}{l}\text { Winsvold et al. } \\
\text { (2013) [36] }\end{array}$ & $\begin{array}{l}\text { HUNT2 and } \\
\text { HUNT3 } \\
\text { general- } \\
\text { population } \\
\text { cohorts, } \\
\text { Norway; 1995- } \\
2008\end{array}$ & $\begin{array}{c}\text { Prospective } \\
\text { cohort; median } \\
\text { follow-up } 11.3 \\
\text { years }\end{array}$ & $\begin{array}{c}19,895 \text { (age } \geq 20, \\
\text { median age } \sim 47 \text { at } \\
\text { baseline) } ; 55 \% \\
\text { female; } 1904(9.6 \%) \\
\text { migraineurs }\end{array}$ & $\begin{array}{l}\text { Modified ATP- } \\
\text { III criteria }\end{array}$ & $\begin{array}{l}\text { Self-reported } \\
\text { questionnaire, } \\
\text { interview; } \\
\text { modified IHS } \\
\text { criteria; } \\
\text { treatment } \mathrm{n} / \mathrm{a}\end{array}$ & - & $\begin{array}{c}21.8 \% \text { in } \\
\text { migraineurs } \\
\text { with aura; } \\
16.8 \% \text { in } \\
\text { migraineurs } \\
\text { without aura } \\
\text { ( } v s 14.5 \% \text { in } \\
\text { subjects with } \\
\text { no headache) }\end{array}$ & $\begin{array}{c}\text { Migraine with } \\
\text { aura: RR } 2.10 \\
(1.53-2.89 \text { in } \\
\text { smokers); } 1.39 \\
\text { (1.03-1.86 in } \\
\text { non-smokers); } \\
\text { migraine without } \\
\text { aura: RR } 1.26 \\
\text { (1.12-1.42); } \\
\text { adjusted for age }\end{array}$ & $\begin{array}{l}\text { Migraine with aura associated } \\
\text { with increased risk for } \\
\text { developing MetS, with effect } \\
\text { modification by smoking status; } \\
\text { moderate risk increase for } \\
\text { migraine without aura not } \\
\text { modified by smoking }\end{array}$ \\
\hline $\begin{array}{l}\text { Fava et al. (2014) } \\
\text { [39] }\end{array}$ & $\begin{array}{l}\text { Hospital } \\
\text { outpatient } \\
\text { headache centre, } \\
\text { Italy; 2011- } \\
2013\end{array}$ & Case-control & $\begin{array}{c}83 \text { CM subjects } \\
\text { (mean age } 41 \pm 5.9), \\
83 \text { EM subjects } \\
\text { (mean age } 40 \pm 4.7) ; \\
83 \text { matched healthy } \\
\text { controls }(100 \% \\
\text { female) }\end{array}$ & IDF criteria & $\begin{array}{l}\text { Clinical exam; } \\
\text { ICHD-3-beta } \\
\text { criteria (IHS); } \\
\text { treatment with } \\
\text { NSAIDs, } \\
\text { triptans, opiates }\end{array}$ & - & $\begin{array}{l}29 \% \text { in } \mathrm{CM}, \\
26 \% \text { in } \mathrm{EM}(v s \\
21 \% \text { in } \\
\text { controls; all } P \\
<0.01)\end{array}$ & $\begin{array}{c}\text { AOR: } 0.88 \\
(0.79-1.16) ; \\
P=0.34 \text { CM } v s \\
\text { EM; adjusted for } \\
\text { age, gender, drug } \\
\text { use, BMI, WC, } \\
\text { depression, } \\
\text { hypertension, } \\
\text { glycaemia, blood }\end{array}$ & $\begin{array}{l}\text { Higher presence of MetS in } \\
\text { migraineurs } v s \text { controls; NS by } \\
\text { EM/CM; significantly increased } \\
\text { risk of insulin resistance, obesity } \\
\text { in CM vs EM; triptans \& } \\
\text { NSAIDs significantly higher in } \\
\text { CM } v s \text { EM }\end{array}$ \\
\hline
\end{tabular}




\begin{tabular}{|c|c|c|c|c|c|c|c|c|c|}
\hline & & & & & & & & $\begin{array}{c}\text { profile, } \mathrm{Hb} 1 \mathrm{Ac} \\
\text { triglycerides }\end{array}$ & \\
\hline $\begin{array}{l}\text { Salmasi et al. } \\
\text { (2014) [49] }\end{array}$ & $\begin{array}{c}\text { Neurology } \\
\text { outpatient } \\
\text { service, Iran; } \\
\text { 2011-2013 }\end{array}$ & $\begin{array}{l}\text { Case-control } \\
\text { (cross-sectional } \\
\text { analysis) }\end{array}$ & $\begin{array}{c}200 \text { migraineurs } \\
\text { (mean age } 34.3 \pm \\
\text { 10.9); } 200 \text { matched } \\
\text { healthy controls; } \\
\text { overall } 81 \% \text { female }\end{array}$ & ATP-III criteria & $\begin{array}{l}\text { Clinical exam; } \\
\text { IHS criteria; } \\
\text { VAS; treatment } \\
\text { n/a }\end{array}$ & - & $\begin{array}{c}17 \% \text { vs } 15 \% \text { in } \\
\text { controls, } P> \\
0.58\end{array}$ & - & $\begin{array}{c}\text { NS correlation between } \\
\text { migraine \& MetS; increased } \\
\text { BMI, WC in migraineurs vs } \\
\text { controls }\end{array}$ \\
\hline $\begin{array}{l}\text { Celikbilek et al. } \\
\text { (2015) [29] }\end{array}$ & $\begin{array}{l}\text { Neurology } \\
\text { outpatient } \\
\text { service, Turkey; } \\
\text { period } \mathrm{n} / \mathrm{a}\end{array}$ & $\begin{array}{l}\text { Case-control } \\
\text { (cross-sectional } \\
\text { analysis) }\end{array}$ & $\begin{array}{c}42 \text { migraineurs } \\
\text { (93\% female); ages } \\
\text { 18-50; median age } \\
\text { 35; } 40 \text { matched } \\
\text { controls }\end{array}$ & ATP-III criteria & $\begin{array}{c}\text { Clinical exam; } \\
\text { ICHD-2 criteria } \\
\text { (IHS); VAS; } \\
\text { without } \\
\text { treatment }\end{array}$ & - & $\begin{array}{c}33 \%(v s 5 \% \text { in } \\
\text { controls; } P= \\
0.001)\end{array}$ & - & $\begin{array}{c}\text { MetS more frequent in } \\
\text { migraineurs } v s \text { controls; attack } \\
\text { frequency lower in migraineurs } \\
\text { with MetS } v s \text { no MetS; NS by } \\
\text { presence of aura }\end{array}$ \\
\hline $\begin{array}{l}\text { Goulart et al. } \\
\text { (2015) [34] }\end{array}$ & $\begin{array}{l}\text { ELSA-Brasil } \\
\text { cohort of civil } \\
\text { servants, Brazil; } \\
\text { 2008-2010 }\end{array}$ & Cross-sectional & $\begin{array}{c}14,953(4411 \\
\text { migraineurs; } 76.2 \% \\
\text { female; mean age } 50 \\
\pm 8.0) \text {; ages } 35-74\end{array}$ & ATP-III criteria & $\begin{array}{l}\text { Self-reported } \\
\text { questionnaire, } \\
\text { IHS criteria; } \\
\text { treatment by } \\
\text { antiepileptics, } \\
\text { beta-blockers, } \\
\text { antidepressants }\end{array}$ & - & $\begin{array}{c}19.9 \%(v s \\
24.3 \% \text { in non- } \\
\text { migraineurs, } P \\
<0.05)\end{array}$ & $\begin{array}{c}\text { OR } 0.65(0.43- \\
0.99) \text { in men; OR } \\
0.88(0.73-1.05) \\
\text { in women; } \\
\text { adjusted for age, } \\
\text { education, race, } \\
\text { income, use of } \\
\text { migraine } \\
\text { prophylaxis drugs }\end{array}$ & $\begin{array}{c}\text { Significant inverse association } \\
\text { between MetS \& definite } \\
\text { migraine only in men; NS for } \\
\text { probable migraine in either } \\
\text { gender; positive association } \\
\text { between migraine (definite, } \\
\text { probable, overall) \& } \\
\text { dyslipidaemia only in women }\end{array}$ \\
\hline $\begin{array}{l}\text { He et al. (2015) } \\
{[17]}\end{array}$ & $\begin{array}{c}\text { Neurology } \\
\text { outpatient } \\
\text { service, China; } \\
2013\end{array}$ & Cross-sectional & $\begin{array}{c}142 \text { migraineurs } \\
\text { (females); ages } 18- \\
65 ; \text { mean age } 43.3 \pm \\
8.3\end{array}$ & ATP-III criteria & $\begin{array}{l}\text { Questionnaire, } \\
\text { clinical exam; } \\
\text { ICHD-2 criteria } \\
\text { (IHS); VAS; } \\
\text { analgesic drug } \\
\text { use; excluding } \\
\text { those using } \\
\text { regular } \\
\text { prophylactic } \\
\text { drugs for past } 3 \\
\text { months }\end{array}$ & - & $12 \%$ & $\begin{array}{l}\text { OR 5.34 (1.16- } \\
24.6) ; P=0.03 ; \\
\text { adjusted for age, } \\
\text { residence, BMI, } \\
\text { waist-to-height } \\
\text { ratio, smoking, } \\
\text { drinking history }\end{array}$ & $\begin{array}{l}\text { Link between CM \& MetS } \\
\text { attenuated after adjustment for } \\
\text { analgesic overuse; NS by } \\
\text { presence of aura }\end{array}$ \\
\hline $\begin{array}{l}\text { Krongsut et al. } \\
\text { (2016) [40] }\end{array}$ & $\begin{array}{l}\text { Headache } \\
\text { outpatient } \\
\text { clinic, Thailand, } \\
2015\end{array}$ & Cross-sectional & $\begin{array}{c}162 \text { adult } \\
\text { migraineurs }(87.2 \% \\
\text { female })\end{array}$ & $\begin{array}{l}\text { Self-reported } \\
\text { during clinic } \\
\text { visit, criteria n/a }\end{array}$ & $\begin{array}{l}\text { Self-reported } \\
\text { diagnosis \& } \\
\text { treatment during } \\
\text { clinic visit, } \\
\text { criteria n/a } \\
\end{array}$ & - & $18.5 \%$ & - & $\begin{array}{l}\text { Male gender, migraine severity } \\
\text { associated with MetS; } \\
\text { association by presence/absence } \\
\text { of aura n/a; NS by migraine } \\
\text { frequency or type of treatment }\end{array}$ \\
\hline $\begin{array}{l}\text { Streel et al. (2017) } \\
\text { [35] }\end{array}$ & $\begin{array}{c}\text { NESCaV } \\
\text { project, } \\
\text { stratified } \\
\text { random sample, } \\
\text { Belgium; 2010- } \\
\end{array}$ & Cross-sectional & $\begin{array}{c}731 \text { with MetS data, } \\
116 \text { migraineurs } \\
\text { without aura } \\
(15.3 \%, \text { median age } \\
39.4,69.8 \% \\
\end{array}$ & $\begin{array}{l}\text { Revised ATP-III } \\
\text { criteria }\end{array}$ & $\begin{array}{l}\text { Self-reported ef- } \\
\text { ID Migraine } \\
\text { questionnaire; } \\
\text { treatment } \mathrm{n} / \mathrm{a}\end{array}$ & - & $\begin{array}{l}28.1 \% \text { in } \\
\text { migraineurs } \\
\text { with aura; } \\
12.8 \% \text { in } \\
\text { migraineurs } \\
\end{array}$ & $\begin{array}{l}\text { OR } 3.45(1.63- \\
\text { 7.29) adjusted for } \\
\text { age, gender, } \\
\text { district, } \\
\text { sedentariness, } \\
\end{array}$ & $\begin{array}{c}\text { Migraineurs with aura at higher } \\
\text { risk of MetS } v \text { non- } \\
\text { migraineurs; NS for migraine } \\
\text { without aura }\end{array}$ \\
\hline
\end{tabular}




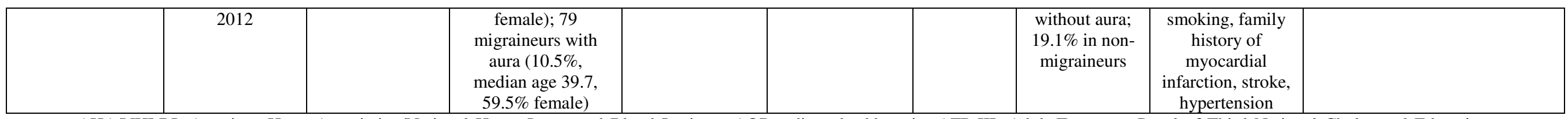

AHA/NHLBI: American Heart Association/National Heart, Lung, and Blood Institute; AOR: adjusted odds ratio; ATP-III: Adult Treatment Panel of Third National Cholesterol Education Program Expert Panel on Detection, Evaluation and Treatment of High Blood Cholesterol in Adults; BMI: body mass index; CM: chronic migraine; EM: episodic migraine; ICD-9-CM: International Classification of Diseases, $9^{\text {th }}$ Revision-Clinical Modification; ICHD: International Classification of Headache Disorders; IDF: International Diabetes Federation; IHS: International Headache Society; n/a: not available or not reported; NESCaV: Nutrition, Environment and Cardiovascular Health; NS: not statistically significant $(P$ > 0.05); NSAIDs: nonsteroidal anti-inflammatory drugs; OR: odds ratio; RR: risk ratio (incidence); VAS: visual analogue scale; WC: waist circumference 